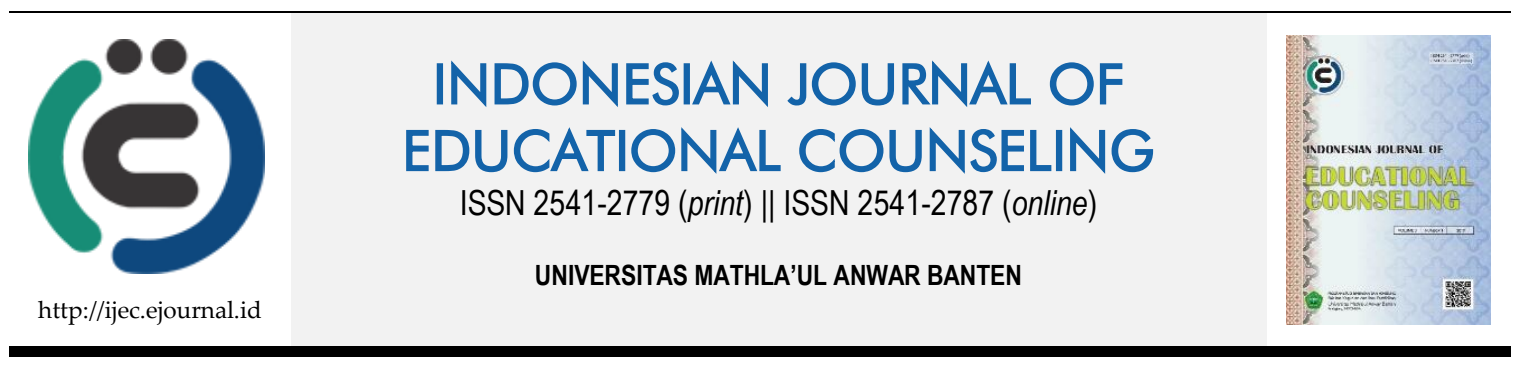

Research Based Article

\title{
Identifikasi Gaya Belajar ditinjau dari Kecenderungan \\ Bakat Khusus pada Mahasiswa Program Studi Bimbingan dan Konseling Universitas Muhammadiyah Metro
}

\author{
Agus Wibowo ${ }^{1}$, Nurul Atieka ${ }^{2}$ \\ 1, 2 Universitas Muhammadiyah Metro
}

\begin{tabular}{ll}
\hline Article History & ABSTRACT \\
\hline $\begin{array}{l}\text { Received: 06.09.2018 } \\
\text { Received in revised form: }\end{array}$ & $\begin{array}{l}\text { Pragmatism of educational practice can be seen from learning process without } \\
\text { based of individual characteristics. This condition appears in the selection of }\end{array}$ \\
Accepted: 11.01 .2019 & methods and strategies of lstudents who tend to be oriented towards teacher \\
Available online: 31.01 .2019 & oriented. In learning identification the characteristics of students are very \\
poorly identified by teachers. Based from the problems, it is very important to \\
study and identify student talents and student learning styles. Through this \\
research, it is expected to be a reference in the development of the learning \\
process based of special talents and student learning styles. This study aims to \\
identify the characteristics of talent, learning styles, and the relationship \\
between talent and learning styles in students. The method used is correlational \\
research. Data collection uses aptitude tests and learning style scales.The results \\
of research is majority students guidance and counseling study program of UM \\
Metro have special talent is vebal talent, dan characteristics of style learning is \\
visual learning. Thus the results of the study also show that the majority of \\
students who have a verbal talent are also types of visual learning. \\
Keywords: Learning Style, Special Talent.
\end{tabular}

DOI: 10.30653/001.201931.52

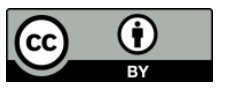

This is an open access article distributed under the terms of the Creative Commons Attribution 4.0 International License, which permits unrestricted use, distribution, and reproduction in any medium, provided the original work is properly cited. (c) 2019 Agus Wibowo, Nurul Atieka.

\section{PENDAHULUAN}

Permasalahan pada dunia pendidikan di Indonesia terletak pada pragmatisme pendidikan dalam melakukan proses pembelajaran. Pendidik cenderung menganggap secara reguler peserta didik dianggap sama, sehingga proses pembelajaran kurang mengakomodir dan memperhatikan karakteristik dan perbedaan individu. Pragmatisme pembelajaran yang dilakukan oleh pendidik bukan saja terjadi pada proses pendidikan di tingkat dasar dan menengah, namun cenderung juga terjadi pada pendidikan tinggi. Proses pembelajaran yang dilakukan dosen masih kurang memperhatikan perbedaan individu. Bakat, minat, dan IQ dari mahasiswa yang pada dasarnya sering tidak dijadikan

${ }^{1}$ Corresponding author's address: Program Studi Bimbingan dan Konseling FKIP Universitas Muhammadiyah Metro, Iringmulyo, Metro Timur, Kota Metro, Lampung 34381; Email: bowokhoirunnas_khairunnasgcc@rocketmail.com 
sebagai pijakan dalam penentuan strategi dan metode pembelajaran. Musrofi (dalam Papilaya \& Huliselan, 2016) menyebutkan bahwa hanya 30\% mahasiswa yang berhasil mengikuti pembelajaran di kelas karena mereka mempunyai gaya belajar yang sesuai dengan gaya mengajar yang diterapkan dosen di dalam kelas. Sisanya, sebanyak 70\% mahasiswa mengalami kesulitan dalam mengikuti pembelajaran di kelas karena mereka memiliki gaya belajar lain, yang tidak sesuai dengan gaya mengajar yang diterapkan di dalam kelas. Artinya, 70\% gaya mahasiswa tidak terakomodasi oleh gaya mengajar dosen dalam pembelajaran keunikan atau perbedaan antar mahasiswa.

Proses pembelajaran yang dilakukan oleh dosen pada program studi Bimbingan dan Konseling (BK) Universitas Muhammadiyah Metro (UM Metro) sangat rendah dalam hal memperhatikan karakteristik individu. Dosen cenderung menggunakan metode dan strategi pembelajaran masih berorientasi pada tujuan, namun karaktersitik gaya belajar mahasiswa masih cenderung tidak menjadi perhatian oleh dosen. Kondisi tersebut berdampak: 1) mahasiswa cenderung bosan mengikuti perkuliahan, 2) pemahaman akan materi menjadi rentan tidak terpenuhi, dan 3) hasil belajar relatif tidak mengalami peningkatan pada setiap semester. Proses pembelajaran yang baik adalah proses pembelajaran yang mengacu kepada keunikan dan karakteristik dari pembelajar.

Berangkat dari kondisi tersebut, penelitian ini mengidentifikasi kecenderungan bakat dan gaya belajar mahasiswa, sehingga diketahui karakteristik gaya belajar mahasiswa dan kaitannya dengan potensi dasar atau bakat. Hasil penelitian diharapkan dapat memberikan gambaran tentang gaya belajar mahasiswa pada setiap karakter bakat yang dimiliki oleh mahasiswa, sehingga menjadi informasi dan pedoman yang bermanfaat bagi dosen dalam menentukan metode dan strategi pembelajaran yang mengakomodir kecenderungan bakat dan karakteristik gaya belajar mahasiswa.

\section{METODE}

Pendekatan penelitian yang digunakan adalah penelitian ex-post facto. Penelitian ini akan mengkalsifikasikan bakat dan gaya belajar mahasiswa selanjutnya akan menguji keterkaitan antar variabel tersebut. Lokasi penelitian adalah di Program Studi Bimbingan dan Konseling Fakultas Keguruan dan Ilmu Pendidikan (FKIP) Universitas Muhammadiyah Metro, Kota Metro Provinsi Lampung.

Sampel penelitian sejumlah 55 mahasiswa aktif program studi bimbingan dan konseling UM Metro. Untuk mengumpulkan data penelitian, maka instrumen yang digunakan adalah: 1) Skala kecenderungan bakat khusus, dan 2) Skala gaya belajar. Analisis deskriptif digunakan untuk menganalisis data secara umum dengan teknik statistik. Analisis deskriptif bertujuan untuk mengelompokkan data sesuai dengan kategori yang ditentukan pada masing-masing variabel. Analisis deskriptif digunakan untuk menentukan presentase disetiap variabel sesuai dengan kategorinya. Data yang berupa interval dikategorikan sesuai dengan jumlah kelas interval untuk mendapatkan hasil analisis deskriptif. Jumlah kelas interval ditentukan dengan rumus Sturges. 


\section{HASIL DAN PEMBAHASAN}

\section{Deskripsi Kecenderungan Bakat Khusus Mahasiswa BK UM Metro}

Instrumen penelitian yang peneliti gunakan untuk mengetahui kecenderungan bakat mahasiswa program studi bimbingan dan konseling UM Metro berupa skala kecenderungan bakat. Instrumen ini disusun untuk mengetahui potensi bakat khusus mahasiswa BK UM Metro yang berupa bakat numerikal dan bakat verbal. Instrumen yang diberikan kepada mahasiswa program studi bimbingan dan konseling sebagai responden terdiri dari lima (5) alternatif jawaban yang akan mengungkapkan kecenderungan bakat, yaitu verbal dan bakat numerikal. Skala kecenderungan bakat diberikan kepada responden penelitian yang berjumlah 55 mahasiswa aktif sementer empat (IV) program studi Bimbingan dan Konseling UM Metro.

Bagi calon konselor bakat verbal menjadi penting karena konselor merupakan profesi yang berkecimpung pada bidang pelayanan. Untuk mengidentifikasi bakat mahasiswa program studi bimbingan dan konseling menggunakan skala bakat khusus. Hasil analisis terhadap data penelitian yang terkumpul disajikan pada Tabel 1.

Tabel 1. Kecenderungan Bakat Khusus Mahasiswa Prodi Bimbingan dan Konseling UM Metro

\begin{tabular}{lll}
\hline Kecenderungan Bakat Khusus & F & $\%$ \\
\hline Verbal & 50 & 90,91 \\
\hline Numerikal & 5 & 9,09 \\
\hline
\end{tabular}

Berdasarkan tabel 1 terlihat bahwa dari 55 responden penelitian, diketahui bahwa secara mayoritas memiliki kecenderungan bakat verbal, yaitu 90,91\% atau 50 responden, dan hanya $9,09 \%$ atau 5 responden yang memiliki bakat khusus numerikal. Hasil analisis menjelaskan bahwa secara mayoritas mahasiswa program studi bimbingan dan konseling memiliki potensi yang sangat tinggi pada bidang verbalistik, dan pada dasarnya hal ini sangat sesuai dengan profesi atau pendidikan yang sedang dijalani, yaitu pendidikan calon guru BK atau konselor yang merupakan profesi yang berkaitan dengan human relationship dan public service.

Profesi bimbingan dan konseling merupakan profesi yang membutuhkan kemampuan bahasa yang tinggi, dengan demikian jika dalam kenyataan mahasiswa memiliki karakteristik bakat daam bidang verbal, itu sangat sesuai untuk pendidikan guru atau konselor. Kualitas komunikasi konselor menjadi hal yang sangat penting. Hal tersebut seperti pendapat Willis (2004, p. 158), yaitu pengembangan hubungan konseling yang ditandai dengan keakraban, keharmonisan, kesesuaian, kecocokkan, dan saling menarik (terbentuk rapport), melalui komunikasi verbal dan non verbal, sehingga konselor yang memiliki bakat verbal diharapkan mampu meningkatkan kualitas layanan bimbingan dan konseling yang dilakukan.

Penyelenggaraan konseling mengandalkan penggunaan sejumlah keterampilan konselor, salah satunya yaitu kemampuan berkomunikasi yang merupakan keterampilan mikro konseling, di samping berbagai keterampilan lainnya (Geldard \& Geldard, 2005; Hariko, 2017) menjelaskan bahwa dalam Berdasarkan beberapa pendapat tersebut, maka potensi dasar yang dimiliki oleh mahasiswa bimbingan dan konseling UM Metro cenderung pada bidang verbal diharapkan sangat mendukung ketercapaian kompetensi konselor. 


\section{Deskripsi Karakteristik Gaya Belajar Mahasiswa Program Studi BK UM Metro}

Pada bagian berikut disajikan deskripsi data hasil penelitianya yang sudah dianalisis tentang karakteristik gaya belajar mahasiswa. untuk mengidentifikasi gaya belajar mahasiswa, peneliti menyusun inventori yang diberikan kepada responden penelitian berjumlah 55 mahasiswa.

Karakteristik gaya belajar mahasiswa program studi bimbingan dan konseling dianalisis menggunakan aplikasi yang disusun oleh peneliti. Berdasarkan inventori gaya belajar, selanjutnya dianalisis, dan hasil analisis serta pengkategorian gaya belajar mahasiswa program studi bimbingan dan konseling UM Metro disajikan pada Tabel 2.

Tabel 2. Karakteristik Gaya Belajar Mahasiswa Prodi Bimbingan dan Konseling UM Metro

\begin{tabular}{lll}
\hline Tipe Gaya Belajar & F & $\%$ \\
\hline Audio & 18 & 32,73 \\
\hline Visual & 26 & 47,27 \\
\hline Kinestetik & 11 & 20 \\
\hline
\end{tabular}

Pada Tabel 2, terlihat bahwa dari 55 responden yang merupakan mahasiswa program studi bimbingan dan konseling UM Metro memiliki karakteristik gaya belajar yang secara kuantitas tidak terlalu signifikan perbedaannya. Secara rinci terlihat bahwa 18 mahasiswa atau 32,73\% memiliki karakteristik gaya belajar audio. Selanjutnya sejumlah 26 mahasiswa atau 47,27\% memiliki karakteristik gaya belajar visual, dan 11 mahasiswa atau $20 \%$ mahasiswa atau berada pada tipe atau karakteristik gaya belajat kinestetik.

Merujuk kepada deskripsi gaya belajar mahasiswa tersebut, di atas terlihat bahwa dalam satu kelas atau satu angkatan terdapat variasi yang cukup imbang diantara tipe belajar mahasiswa program studi bimbingan dan konseling UM Metro. Gaya belajar adalah kecenderungan yang dimiliki oleh individu dalam melakukan aktifitas belajar. Gaya belajar merupakan cara belajar yang khas bagi siswa (Winkel, 2009), dimana merupakan cara siswa bereaksi dan menggunakan perangsang-perangsang yang diterimanya dalam proses belajar (Nasution, 2003, p. 55).

Penjelasan di atas menggambarkan bahwa mahasiswa bimbingan dan konseling memiliki karakter gaya belajar yang cukup bervariasi, dan tidak ada yang dominan. Oleh karenanya dalam pembelajaran dikelas, dosen hendaknya dapat mengakomodir karakteristik yang berbeda dari mahasiswa tersebut untuk lebih kreatif, inovatif, dan juga melaksanakan pembelajaran yang dinamis bukan hanya sekedar ceramah.

Terdapat tiga jenis gaya belajar berdasarkan modalitas yang digunakan individu dalam memproses informasi (perceptual modality). Ketiga gaya belajar tersebut adalah gaya belajar visual (belajar dengan cara melihat), auditorial (belajar dengan cara mendengar), dan kinestetik (belajar dengan cara bergerak, bekerja, dan menyentuh) (DePorter, Reardon, \& Singer-Nourie, 2009).

Merujuk kategorisasi gaya belajar mahasiswa tersebut di atas, menunjukkan bahwa dalam perkuliahan mahasiswa program studi bimbingan dan konseling memiliki karakter gaya belajar audio, visual, dan kinestetik. Individu yang memiliki Gaya Belajar visual memiliki kecenderungan lebih senang melihat apa yang sedang dipelajari. Sementara itu, individu yang cenderung memiliki gaya belajar auditorial kemungkinan belajar lebih baik dengan mendengarkan, dan untuk individu yang memiliki tipe gaya 
belajar kinestetik dapat belajar lebih baik apabila terlibat secara fisik dalam kegiatan langsung (DePorter, Reardon, \& Singer-Nourie, 2009).

\section{Karakteristik Gaya Belajar ditinjau dari Kecenderungan Bakat pada Mahasiswa Prodi BK UM Metro.}

Setelah mengetahui deskripsi dari kecenderungan bakat khusus mahasiswa dan juga karakteristik gaya belajar mahasiswa program studi bimbingan dan konseling Universitas Muhammadiyah Metro, maka selanjutnya akan diidentifikasi bagaimana karakteristik gaya belajar dari mahasiswa ditinjau dari bakat yang dimiliki. Hasil analisis data identifikasi karakteristik gaya belajar mahasiswa ditinjau dari bakat khusus yang dimiliki disajikan dalam Tabel 3.

Tabel 3. Identifikasi Gaya Belajar ditinjau dari Bakat Khusus

\begin{tabular}{lll}
\hline Kombinasi Bakat Dengan Gaya Belajar & F & $\%$ \\
\hline Verbal- Audio & 15 & 27,27 \\
\hline Verbal-Visual & 24 & 43,64 \\
\hline Verbal- Kinestetik & 11 & 20,00 \\
\hline Numerikal-Audio & 2 & 3,64 \\
\hline Numerikal-Visual & 2 & 3,64 \\
\hline Numerikal- Kinestetik & 1 & 1,82 \\
\hline & 55 & 100 \\
\hline
\end{tabular}

Tabel 3 menjelaskan bahwa terdapat variasi yang terdiri dari enam (6) bentuk kombinasi antara tipe bakat khusus mahasiswa dengan karakteristik tipe gaya belajar. Sajian data tersebut di atas juga disajikan pada Gambar 1.

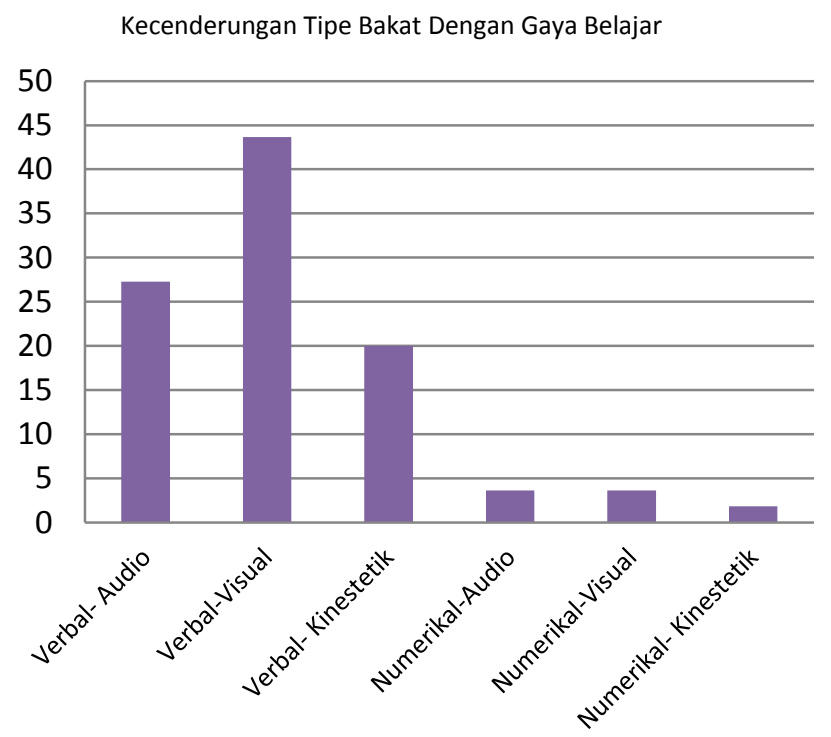

Gambar 1. Diagram Kombinasi Bakat dan Gaya Belajar

Hasil penelitian menunjukkan bahwa terdapat variasi antara bakat khusus dan juga gaya belajar mahasiswa, yaitu kombinasi yang memiliki bakat khusus verbal dan memiliki tipe gaya belajar Audio sejumlah 15 mahasiswa dengan persentase 27,27\%, tipe bakat khusus verbal dengan tipe gaya belajar visual sebanyak 24 mahasiswa atau 43,64\%, 
yang memiliki bakat khusus verbal dan bergaya belajar kinestetik sejumlah 11 orang dengan persentase 3,64 .

Selanjutnya pada mahasiswa yang memiliki bakat khusus numerik yang tipe gaya belajarnya audio berjumlah 2 mahasiswa atau 3,64\%, yang memiliki bakat khusus numerik dan bertipe belajar visual sebanyak 2 mahasiswa dengan persentase 3,64\%, dan yang memiliki karakteristik bakat numerik dan memiiki tipe belajar kinestetik berjumlah 1 mahasiswa atau $1,82 \%$.

Berdasarkan sajian data tersebut di atas, maka dapat dirumuskan kesimpulan bahwa secara umum mahasiswa program studi bimbingan dan konseling memiliki kecenderungan bakat khusus pada bidang verbal, dan gaya belajar secara dominan bertipe visual, sehingga karakteristik mahasiswa program studi bimbingan dan konseling cenderung memiliki bakat verbal dengan tipe belajar visual.

\section{SIMPULAN}

Mahasiswa program studi bimbingan dan konseling Universitas Muhammadiyah Metro memiliki kecenderungan bakat khusus pada bidang verbalistik atau bakat verbal. Karakteristik tipe gaya belajar mahasiswa program studi bimbingan dan konseling Universitas Muhammadiyah Metro pada setiap tipe belajar memiliki persentase yang hampir sama, namun yang paling dominan adalah tipe belajar visual. Secara umum mahasiswa program studi bimbingan dan konseling memiliki kecenderungan bakat khusus pada bidang verbal, dan gaya belajar secara dominan bertipe visual. Dengan demikian, karakteristik mahasiswa program studi bimbingan dan konseling cenderung memiliki bakat verbal dengan tipe belajar visual.

\section{REFERENSI}

Bire, A. L., Geradus, U., \& Bire, J. (2014). Pengaruh gaya belajar visual, auditorial, dan kinestetik terhadap prestasi belajar siswa. Jurnal Kependidikan: Penelitian Inovasi Pembelajaran, 44(2), 168-174.

DePorter, B., Reardon, M., \& Singer-Nourie, S. (2009). Quantum teaching. Bandung: Kaifa.

Geldard, K., \& Geldard, D. (2005). Practical counselling skills: An integrative approach. Basingstoke: Palgrave Macmillan

Hariko, R. (2017). Landasan filosofis keterampilan komunikasi konseling. Jurnal Kajian Bimbingan dan Konseling, 2(2), 41-49.

Nasution, S. (2003). Berbagai pendekatan dalam proses belajar dan mengajar. Jakarta: Bumi Aksara.

Papilaya, J. O., \& Huliselan, N. (2016). Identifikasi gaya belajar mahasiswa. Jurnal Psikologi, 15(1), 56-63.

Willis, S. (2007). Teori dan teknik konseling di sekolah. Yogyakarta: Rineka Cipta. 